\title{
MALAYA'S GREATEST MENACE? SLOW-ONSET DISASTER AND THE MUDDY POLITICS OF BRITISH MALAYA, C. 1900-50
}

FIONA WILLIAMSON

\section{Abstract}

In 1948, a chilling statement from British Malaya's Director of Agriculture, F. Burnett, made headline news. According to Burnett, unchecked soil erosion across hillside Malaya would soon render the country's precious agricultural land infertile. Erosion had worsened considerably after the 1880 s due to widespread, indiscriminate agricultural and industrial clearing. By the 1920s, it had become a sizeable socioeconomic and environmental issue, thought also to contribute to the scale and intensity of flooding and the likelihood of dangerous landslips. The British Government raised a series of empire-wide inquiries across the first half of the twentieth century, tied to an emerging global scientific interest in, and concern about, soil degradation, food security and economic productivity. The colonial British Government of Malaya-whilst acknowledging the part played by commercial agriculture-also tended to place blame on traditional shifting cultivators and farmers, especially the Chinese. This article discusses the problem of soil erosion in British Malaya as a primarily slow-onset disaster while also acknowledging erosion's contributing role in more sudden hazards, such as landslips. It also explores how erosion was linked with an evolving blame culture in Malaya, involving discrimination against different social groups at different times. The narratives surrounding soil erosion thus offer a lens into the interplay of environment, colonialism and politics in British Malaya.

Keywords: soil erosion, denudation, floods, British Malaya, slow-onset disaster, blame

\section{Introduction: Narratives of fear in an evolving global problem}

[A]griculture in fertile valley bottoms allowed populations to grow to the point where they came to rely on farming sloping land. Geologically rapid erosion of hillslope soils followed when vegetation clearing and sustained tilling exposed bare soil to rainfall and runoff. During subsequent centuries, nutrient depletion or soil 
loss from increasingly intensive farming stressed local populations as crop yields declined and new land was unavailable. Eventually, soil degradation translated into inadequate agricultural capacity to support a burgeoning population, predisposing whole civilisations to failure. ${ }^{1}$

David Montgomery's bleak summation reminds us of the critical importance of good soil management to the survival of empires and nations. By the early twentieth century, erosion in many parts of the world, including America, China, Africa, Australia and India, had reached a scale whereby many feared the worst. Resulting in diminished agricultural productivity, desertification, landslips and the intensification of floods and droughts, erosion was considered an incubating and active disaster. In the dominions and colonies of Britain's Far Eastern empire, colonial authorities had largely desisted from addressing the problem throughout the rapid land use changes of the nineteenth century. Ill-prepared to meet the challenges set by the geological and climatic features of the tropics, heat and high rainfall combined with degradation wrought by intensive plantation agriculture and industrial mining. Sheet and gulley erosion were common features of upland slopes where forests had made way for commercial crops.

It was commonly thought at the time that deforestation affected localised climates (desiccation) and contributed to an increase in flooding. ${ }^{2}$ Jungle and vegetation clearances near rivers and streams increased surface water run-off, channelling rains through the deep gullies to bloat streams and rivers. Man-made flood prevention schemes often made the situation worse. The desire to protect prime agricultural land and settlements in river valleys had led to an increase in levees and embankments, which confined flood waters and, in some cases, exacerbated and prolonged flooding. Left in its natural state, a river in flood would deposit nutrient-rich silt across its floodplain. ${ }^{3}$ With embanking, soil particles drop to the bottom of the riverbed as the levee decreases normal water velocity. ${ }^{4}$ This created a catch-22 situation whereby

1 David R. Montgomery, Dirt: The Erosion of Civilizations (Berkeley, CA: University of California Press, 2007), 5-6.

2 For an excellent introduction to these themes historically, see Richard Grove, Ecology, Climate and Empire: Colonialism and Global Environmental History, 1400-1940 (Cambridge: White Horse Press, 1997).

3 James Rennell, 'An Account of the Ganges and Burrampooter Rivers', Philosophical Transactions of the Royal Society of London 71 (1781): 87-114, doi.org/10.1098/rstl.1781.0031; Rohan D’Souza, 'River as Resource and Land to Own: The Great Hydraulic Transition in Eastern India', Conference Paper for Asian Environments Shaping the World: Conceptions of Nature and Environmental Practices (National University of Singapore, 2009), 20.

4 R. J. Wasson, 'Exploitation and Conservation of Soil in South Asia', in Soils and Societies: Perspectives from Environmental History, ed. J. R. McNeill and Verena Winiwarter (Isle of Harris: The White Horse Press, 2006), 38. 
levees were increased as the riverbed rose year-on-year, which, as Elspeth Huxley wryly noted, was 'a game that nature ... is likely to win'. ${ }^{5}$ In extreme cases of slope denudation, landslips became more likely. ${ }^{6}$

From the arid regions of Africa to the moist humidity of the tropics, by the early twentieth century the prevailing assessment of state-led and indigenous forest, mining and soil management practices had created an 'alarmist discourse on environmental degradation' and a sense of an unfolding environmental crisis.7 Inspired by their experiences in colonial Asia and Africa, geographers and scientists, including Ellsworth Huntington and Charles Brooks, wrote influential texts on man-induced environmental degradation and climate change. ${ }^{8}$ The former of course was renowned for his strong (and increasingly unpopular) opinions on climatic determinism. The publication of Vanishing Lands in 1939 by G. V. Jacks and R. O. Whyte stimulated thinking about man-made soil erosion as a global catastrophe subsequent to the 'twin disasters' of wind and water erosion that had led to the American Dust Bowl of the 1920s and 1930s. ${ }^{9}$ This tragedy alone had presaged an unprecedented political, popular and scientific interest in soil erosion. ${ }^{10}$ A press report from the 1938 Conference of Colonial Directors of Agriculture held in London reveals the new anxieties in the discourse quite explicitly:

Soil erosion and nutrition are the two most important subjects to be discussed ... speaking on the dangers of soil erosion, Lord Dufferin said it was only during the past few years that the importance of soil conservation had been fully realised, largely as result of the accounts of the position in the United States. ${ }^{11}$

The Commission of Forestry Research in Africa reports of the early 1940s are likewise revealing of the shift in tone and in thinking. Accounts from Mauritania, Chad and the Belgian Congo styled erosion as 'a serious threat to the whole of mankind'. In the African context, the diminution of rainfall, the drying up of water

\footnotetext{
5 Elspeth Huxley, 'The Menace of Soil Erosion', Journal of the Royal African Society 36, no. 144 (1937): 360, doi.org/10.1093/oxfordjournals.afraf.a101460.

6 Maryam Khosrokhani and Biswajeet Pradhan, 'Spatio-temporal assessment of soil erosion at Kuala Lumpur metropolitan city using remote sensing data and GIS', Geomatics, Natural Hazards and Risk 5, no. 3 (2014): 252-70, doi.org/10.1080/19475705.2013.794164.

7 V. Saberwal, Pastoral Politics (Delhi: Oxford University Press, 1999), quoted in Wasson, 'Exploitation and Conservation', 39.

8 Richard Grove and Vinita Damodaran, 'Environment', in The Ashgate Research Companion to Modern Imperial Histories, ed. Philippa Levine and John Marriott (London and New York: Routledge, 2012), 572. See also Ellsworth Huntington, The Pulse of Asia (London: Constable, 1907) or C. E. P. Brooks, The Evolution of Climate (London: Benn, 1922).

9 G. V. Jacks and R. O. Whyte, Vanishing Lands: A World Survey of Soil Erosion (New York: Doubleday, Doran \& Co., 1939).

10 Wasson, 'Exploitation and Conservation', 35; Piers Blaikie and Harold Brookfield, Land Degradation and Society (London: Routledge, 1985), 225; D. M. Anderson, 'Depression, Dustbowl, Demography and Drought: The Colonial State and Soil Conservation in East Africa during the 1930s', African Affairs 83 (1984): 321-44, doi.org/10.1093/oxfordjournals.afraf.a097622.

11 'Colonial Office Parley on Soil Erosion', The China Mail, 26 July 1938.
} 
courses and desertification were described as ongoing and ever-increasing disasters of extreme proportions. ${ }^{12}$ The prolific author and researcher of colonial forestry Edward Stebbing argued that a government-sponsored study of the 'direct or indirect action of erosion on water courses and on atmospheric rainfall' was absolutely essential, warning of the dire consequences of desiccation and desertification. At the same time, A. H. W. Weir, the recently retired Chief Conservator of Forests for Nigeria, noted how, across the empire, 'cash crops', including rubber, 'were in jeopardy'. ${ }^{13}$ The African reports (known collectively as the Stebbing Report) were condemned by many however, partly because of their lack of global focus. ${ }^{14}$

In Malaya, official and public awareness of the dangers of soil erosion followed a similar trajectory. Though denudation and desiccation had been topics of scientific interest since the 1840s, it was only after 1910 that erosion began appearing in the everyday press with any regularity. In 1911 , for example, an inquiry examining 'the denudation of the soil owing to the destruction of the forests', originally published in the Indian Forester, was reprinted in The Straits Times, the Malayan daily paper. ${ }^{15}$ Within 30 years, the pitch of such reports had acquired new levels, with warnings issued in the same paper over the course of 1948 that 'Malaya is Being Washed Away!' and 'Stop Erosion-Or Die!' ${ }^{16}$ Comments such as that from long-time plantation manager Jacques Le Doux shed some light on the types of knowledge that were circulating. Writing to his old friend Henry Ridley from his Johore estate in 1949, Le Doux explained how he had been anxiously reading about the global problem in an article. Drawing parallels between the African experience and the Malayan one, especially with regard to 'an incipient development of climatic extremes of wet and dry seasons' whereby erosion would be exacerbated, he went on to note that the 'terrible winter of 1946-7, followed by equally terrible floods, is [in Malaya such] an instance'. ${ }^{17}$

12 Soil Erosion (Part 1). Commission of Research: Africa, 1st Session, 2 January 1942, 3. Remarks submitted by the Members of the Commission and others on the Proceedings of the First Three Sessions, 9. CO 852/394/14. The National Archives (TNA), London.

13 ibid., 18, 20. A short biography of Weir can be found here: W. A. Fairbairn, 'A. H. W. Weir', Forestry 35, no. 2 (1962): 199-200.

14 Soil Erosion. Unfoliated. Note to Dr Tempany on the Report of the Commission of Research on Deforestation in Africa and other tropical countries, unsigned, n.d., 1941. CO 852/394/14. TNA. The 'Stebbing Commission' report was not well received in Britain. It was criticised by several leading experts, and the Colonial Office even refused the money to have it printed.

15 'Forests and Rainfall', The Straits Times, 10 June 1911.

16 'Malaya Is Being Washed Away!', The Straits Times, 19 May 1948, 6; 'Stop Erosion-Or Die', The Straits Times, 6 June 1948, 6.

17 Jacques Le Doux to Ridley, 20 March 1949. Henry Ridley Papers (HNR) 2/1/2, f. 61. Correspondence: Letters to H. N. Ridley CLE GUR. Royal Botanic Gardens Archive, Kew. 
This article draws on several important ideas and approaches in recent environmental history. It pays particular attention to two trajectories of thought. First, the discussion understands erosion as being linked to a range of global and local concerns, many drawing on colonial contexts. As J. R. McNeill describes it in his overview of erosion history, the period from roughly 1840 to 1940 witnessed the transplantation of unsuitable European agricultural methods into Asia and Africa on an unprecedented scale. Imperial expansion came with political and cultural trappings that alienated or removed traditional systems of land tenure and farming rights, in many cases endangering and irrevocably altering time-honoured-often less environmentally disruptive-forms of farming. ${ }^{18}$ Richard Grove's ground-breaking work has also been instrumental in understanding the place of European colonialism in destructive land use, ${ }^{19}$ as have various studies of colonial ecology across Africa and India. ${ }^{20}$

The period also witnessed shifts in environmental thought, many of which had a clear relationship to colonial politics. Piers Blaikie and Harold Brookfield argued in the mid-1980s that soil politics was a fundamental part of pre-capitalist, colonial and post-colonial societies. ${ }^{21}$ Certainly this can be seen in Jeyamalar KathirithambyWells' seminal study of Malaya's environmental history, in which soil emerged as a fundamental component in that country's linked environmental, social and political landscape. ${ }^{22}$ Gregory Barton explored the newly emergent forms of environmental consciousness in the context of imperial forestry, arguing that the period witnessed an increasingly holistic association of climate, soil, water, flora, fauna, and human and environmental health. ${ }^{23} \mathrm{~J}$. M. Powell's exploration of five British Empire forestry conferences (1920 to 1947) explained how these theories were put into practice. Worried about the potential exhaustion of food and timber supplies due to successive international political and environmental crises following 1914, pioneers of the new holistic view of the environment stressed the importance of joined-up

18 J. R. McNeill, Something New under the Sun: An Environmental History of the Twentieth-Century World (New York: W. W. Norton \& Co., 2000), 38-43.

19 Grove, Ecology, Climate and Empire, 37-85.

20 For example, M. Musemwa, 'From Wanton Destruction of Timber Forests to Environmentalism: The Rise of Colonial Environmental and "Sustainability" Practices in Colonial Zimbabwe, 1938-1961', Environment and History 22 (2016): 521-59, doi.org/10.3197/096734016X14727286515772; W. O. Mulwafu, 'Soil Erosion and State Intervention into Estate Production in the Shire Highlands Economy of Colonial Malawi, 1891-1964', Journal of Southern African Studies 28, no. 1 (2002): 25-43, doi.org/10.1080/03057070120116962; P. Delius and S. Schirmer, 'Soil Conservation in a Racially Ordered Society: South Africa, 1930-1970', Journal of Southern African Studies 26, no. 4 (2000): 719-42, doi.org/10.1080/713683610; J. McGregor, 'Conservation, Control and Ecological Change: The Politics and Ecology of Colonial Conservation in Shurugwi', Environment and History 1, no. 3 (1995): 257-79, doi.org/10.3197/096734095779522573.

21 Piers Blaikie and Harold Brookfield, Land Degradation and Society (London: Routledge, 1985); Piers Blaikie, The Political Economy of Soil Erosion in Developing Counties (London: Longman, 1985).

22 Jeyamalar Kathirithamby-Wells, Nature and Nation: Forests and Development in Peninsular Malaysia (Singapore: NUS Press, 2005).

23 Gregory Barton, 'Empire Forestry and the Origins of Environmentalism', Journal of Historical Geography 27, no. 4 (2001): 529-52, doi.org/10.1006/jhge.2001.0353. 
solutions that treated forest, water and soil in parallel. ${ }^{24}$ The Malthusian economics popular in America and Britain across the late nineteenth and early twentieth centuries infused political and environmental narratives with fear over food and resource security in the face of a rising population. The first half of the twentieth century saw an amalgamation of extreme circumstances that worsened the situation. The First World War starkly highlighted the empire's inability to maintain its own internal timber supply, despite having a considerable proportion of the world's forests at its disposal. ${ }^{25}$ Between the wars, the floods and droughts that affected several regions of the world during the mid-1920s and the American Dust Bowl had an incredible impact on the contemporary mindset globally, striking fear into politicians' hearts over how environmental degradation-especially soil erosion and deforestation-was threatening international economic and agricultural stability. Certainly, many modern studies have echoed the views of the past, arguing 'how profoundly soil fertility and soil erosion shaped the course of history. ${ }^{26}$ Likewise, the story of soil and soil science fits well with the observation that the 'prediction that the whole global system was falling into degradation was co-determined with the very discovery of that system'. ${ }^{27}$

Second, this article understands the narrative surrounding soil erosion in Malaya as a largely constructed phenomenon. As Le Doux alerts us in his letter, his fearful knowledge about the crisis derived largely from the global literature and the situation overseas, not his experience on the ground in Malaya. There, although the situation was one of great concern, the most intense anxieties were being voiced in respect to the potentiality for disaster, partly in response to a constructed narrative. The construction of an erosion narrative in Malaya derived from three main interlinked sources - first, global scientific dialogue; second, colonial interests and assumptions; and, third, political concerns on the ground. This narrative became a part of the reality. Its entrenchment within colonial ecology also complicated the capacity for solutions by bearing on, or being part of, the particular sets of sociocultural assumptions of that time and place. ${ }^{28}$ Thus erosion operated as an active background that influenced, or derived from, dominant political narratives and, at times, was also appropriated as a political tool by different individuals or groups. The rhetoric of 1948 for example, that immediate action was critical to prevent Malayass lands

24 J. M. Powell, 'Dominion Over Palm and Pine': The British Empire Forestry Conferences, 1920-1947', Journal of Historical Geography 33 (2007): 855, doi.org/10.1016/j.jhg.2006.07.001.

25 For more on the timber industry between 1918 and 1945, see Richard P. Tucker, 'The World Wars and the Globalisation of Timber Cutting', in Natural Enemy, Natural Ally: Toward an Environmental History of War, ed. Richard P. Tucker and Edmund P. Russell (Corvallis, OR: Oregon State University Press, 2004), 110-41.

26 Montgomery, Dirt, 2. See also McNeill and Winiwarter, Soils and Societies.

27 Libby Robin, Sorlin Sverker and Paul Warde, eds, The Future of Nature: Documents of Global Change (New Haven, CT: Yale University Press, 2013), 63.

28 For discussion of how culture 'creates' historic and modern disasters, see Fred Kruger, Greg Bankoff and Terry Cannon, eds, Cultures and Disasters: Understanding Cultural Framings in Disaster Risk Reduction (London and New York: Routledge, 2015); Christof Mauch and Christian Pfister, eds, Natural Disasters, Cultural Responses: Case Studies toward a Global Environmental History (Lanham, MD: Lexington Books, 2009). 
from becoming barren, was intimately connected to the anti-Japanese propaganda of the immediate post-war regeneration government. ${ }^{29}$ In profiling this slow-onset disaster therefore, this article aims to tease out some of the wider social and political matters extant in the Malayan context, especially the connection of the soil problem with the scapegoating of marginal communities, or vilified peoples, which differed over time as mainstream politics shifted. In so doing, it explores the interplay of environment with complex, evolving ideas on peoples, cultures and politics.

Underpinning the entire discussion is the conception of soil erosion in British Malaya as a slow-onset, embryonic disaster. ${ }^{30}$ Building on recent work by disaster historians who have argued that the range of what is considered disastrous should encompass not only the exceptional 'once in a century' grand-scale events, it envisages erosion as ongoing, 'persistent risk' events that shaped everyday lives and cultures. ${ }^{31}$ As Rebecca Jones reminds us in her recent monograph on drought culture in Australia, ongoing 'slow catastrophes' should be conceived of as 'a lived experience'. ${ }^{32}$ Nevertheless, as Mark Baker argues in his essay within this special issue, it ought not be forgotten that disasters rarely operate within one temporality. Whilst lacking the sensationalism of other nature-induced disasters, erosion can contribute to more dramatic problems, including sudden landslips and more intense floods, some of which will be explored here. ${ }^{33}$

The direction of this article is threefold. First, whilst it cannot be doubted that soil erosion was deemed a menace throughout the '20s and '30s globally, ${ }^{34}$ it seeks to explore how far the fear of an impending disaster was justified in British Malaya. Shock headlines and alarmist descriptions often stand in contrast to some contemporary reports from district officers (DOs) stationed around the country, or

\footnotetext{
29 Statement by Federation Director of Agriculture F. Burnett, as reported to the staff correspondent, The Straits Times, 8 April 1948, 10.

30 'Disaster' rather than 'hazard' is considered appropriate, if we take the definition that 'hazards' refer to nature's 'behaviour', whereas disasters reflect the interaction between hazards and human vulnerability: Filomeno V. Aguilar Jr, Michael D. Pante and Angelli F. Tugado, 'Disasters in History and the History of Disasters: Some Key Issues', Philippine Studies: Historical and Ethnographical Viewpoints 64, nos 3-4 (2016): 647.

31 Greg Bankoff and Joseph Christensen, eds, Natural Hazards and Peoples in the Indian Ocean World (New York: Palgrave Macmillan, 2016), 6; James Warren, 'Typhoons and the Inequalities of Philippine Society and History', Philippine Studies: Historical and Ethnographic Viewpoints 64, nos 3-4 (2016): 457, doi.org/10.1353/ phs.2016.0036.

32 Rebecca Jones, Slow Catastrophes: Living with Drought in Australia (Clayton, Vic.: Monash University Publishing, 2017), Introduction.

33 The role erosion was thought to play in exacerbating floods was a factor in many governmental initiatives to alienate hillside forests globally. For more, see Deborah Sutton, 'Redeeming Wood by Destroying the Forest: Shola, Plantations, and Colonial Conservancy on the Nilgiris in the Nineteenth Century', in The British Empire and the Natural World: Environmental Encounters in South Asia, ed. Deepak Kumar, Vinita Damodaran and Rohan D'Souza (Oxford: Oxford University Press, 2011), 91.

34 Both Hammond Bennet and Elspeth Huxley used the word 'menace' to describe soil erosion. See H. H. Bennett and W. R. Chapline, Soil Erosion A National Menace, United States Department of Agriculture Circular No. 33 (Washington, DC: Government Printing Office, 1928); Huxley, 'The Menace of Soil Erosion'. The term was used frequently in the press to describe the situation in Malaya, for example: 'Fighting Menace Of Soil Erosion In Penang', The Straits Times, 12 July 1939, 18; 'Erosion Threat To Malaya', The Straits Times, 8 April 1948, 10.
} 
official reports by contemporary experts who, by the late ' $40 \mathrm{~s}$, were able to argue that the situation in Malaya was largely under control (as compared to elsewhere in the empire). Second, this paper explores how the menace was thought manifest in localised disasters, contributing to river siltation and thus exacerbating the scale of subsequent floods, for instance, or in contributing to landslips. Today, the connection of deforestation, erosion and flooding is subject to some debate, but it is not the intention of this article to argue the case one way or the other. ${ }^{35}$ There is little doubt, however, that the erosion-flood linkage dominated and informed field research and policy at the time; therefore, this article will work within this strand of scientific thought. Finally, it draws attention to how the subject of historical soil erosion can be employed as a lens on contemporary relationships between government and people and the dominant political and cultural narratives of the day.

\section{Moving toward disaster: Changing land practices in Malaya}

British Malaya was once covered with montane ericaceous, oak-laurel and dipterocarp forests, peat lands, mangrove and freshwater swamps. ${ }^{36}$ The lowland dipterocarp and coastal mangrove forests were increasingly cleared to support urbanisation, mining and plantation agriculture throughout the nineteenth century, although traditional small-scale and subsistence farming, especially shifting cultivation, continued to be practised. Chinese and Malay farmers had been practising plantation-style farming for gambier and rice long before the British arrived in Malaya. The Malays cultivated rice in upland areas, their methods described in detail by Thomas John Newbold, soldier, amateur geologist, orientalist and Royal Society Fellow, in the 1830s:

Marking out land for clearance during late spring (dry season), an extended family would clear the ground in two stages. The first (tebbas, menebbas) consisted of cutting smaller brushwood and vegetation before felling trees (tebbang menebbang) with small tools known as prang and bilhong. This process is achieved in one of two ways, either by erecting a stage by which to remove the top parts of the tree until the whole is weakened sufficiently to pull it down, or to cut a number of trees in one area half through on one side and, choosing a large tree to push it down so that it knocks the remaining weakened trees as it falls. The wasting of timber in this process is

35 See Wasson, 'Exploitation And Conservation', 39-44; Albert I. J. M. Van Dijk, 'Forest-Flood Relation Still Tenuous-Comment On "Global Evidence That Deforestation Amplifies Flood Risk And Severity In The Developing World” by C. J. A. Bradshaw, N. S. Sodi, K. S.-H. Peh \& B. W. Brook', Global Change Biology 15 (2009): 110-15, doi.org/10.1111/j.1365-2486.2008.01708.x. For historical perspectives, see Richard Grove, Green Imperialism: Colonial Expansion, Tropical Island Edens and the Origins of Environmentalism, 1600-1860 (Cambridge: Cambridge University Press, 1995), 95-6, 102.

36 WWF-Malaysia, 'The Malaysian Rainforest': www.wwf.org.my/about_wwf/what_we_do/forests_main/the_ malaysian_rainforest, accessed 28 May 2018. 
not considered problematic as it is not considered of value in such small quantities. When dried, the timber and brushwood are burned and the ground is effectively cleared. The ash is then used to fertilise the soil. ${ }^{37}$

With European investment in plantation farming, wealthier Chinese and Malay farmers competed accordingly, enabled by legal changes. ${ }^{38}$ A system of short-term land leases aimed at encouraging smallholders was the norm (especially in Singapore) until the 1830s. But it was deeply unpopular and, in 1836, the Malayan Agricultural and Horticultural Society petitioned that, although 'the soil ... was suited to the cultivation of cotton, sugar, pepper, and nutmegs', commercial investment was unlikely until 'a more liberal system of sale or leasing of land was adopted'. ${ }^{39}$ The controversy led to the appointment of an independent commissioner from India, Mr Young, to make a report on the existing system. Young concurred that the system was actively discouraging long-term investment and argued vociferously that the only means of utilising the land at a profit currently was to extract timber and burn charcoal, or to plant wasteful and 'exhausting' crops such as gambier (the gambier planter was, in his opinion, 'the locust of cultivation'). ${ }^{40}$ Over the course of the century the law was gradually changed to privilege the commercial plantation owner. By the early 1900s, rubber and pineapple had become the crops of choice, stimulated by the new automobile industry and the development of canning technologies. ${ }^{41}$ The Chinese were early investors in rubber as, increasingly, were Malays and Indians, but it was the joint-stock holding companies that owned the largest plantations. ${ }^{42}$ Land enactments in 1897, 1903 and 1911 and the establishment of a Malayan Agricultural Department in 1905 helped incentivise investors. ${ }^{43}$

Of course, the transition from small-scale farming to large-scale commercial agriculture had a significant impact on the environment. The connection of manmade environmental degradation with erosion, changes in soil quality, local climate and the increased potentiality for disaster had been made early on in Malaya. In 1826, Captain James Low, military officer to the English East India Company, had noted how important it was to bolster the soil with compost. Discussing Penang Island (the first British settlement in Malaya), he argued that its upland soils were predominantly 'decomposed granite' so 'disintegration proceeds, in some

37 T. J. Newbold, Political and Statistical Account of the British Settlements in the Straits of Malaya (London: John Murray, 1839), 260-1.

38 Naidu Ratnala Thulaja, 'Gambier': eresources.nlb.gov.sg/infopedia/articles/SIP_337_2005-01-03.html, accessed 28 May 2018.

39 Walter Makepeace, Gilbert Brooke and Roland St J. Braddell, One Hundred Years of Singapore (London: John Murray, 1921), 302-6.

40 ibid., 308.

41 Vernon Cornelius-Takahama, 'Lim Nee Soon': eresources.nlb.gov.sg/infopedia/articles/SIP_526_2009-0107.html, accessed 28 May 2018.

42 J. H. Drabble, 'The Plantation Rubber Industry in Malaya up to 1922', Journal of the Malaysian Branch of the Royal Asiatic Society 40, no. 1 (1967): 56.

43 ibid., 60. 
places, with a rapidity that would not be suspected by a person unacquainted with the nature of that rock'. ${ }^{44}$ Two decades later, James Richardson Logan, editor of the Journal of the Indian Archipelago and Eastern Asia and advocate of desiccation theory, argued:

the whole eastern front (of a mountain range in Penang) has within a few years been denuded of its forest ... in all probability after the fecundity of the fresh soil, enriched by the ashes of the trees, has been exhausted, it will be abandoned by the Chinese squatters. ${ }^{45}$

The idea of the soil as a dynamic system had gained traction in the mid to late 1800s. The pioneering geologist James Hutton had proposed almost 100 years earlier that the earth went through continual cycles of erosion, deposition and sedimentation that helped to constantly renew and recreate the landscape. ${ }^{46} \mathrm{His}$ work was built on by scholars, including Charles Darwin, whose pioneering (if somewhat misunderstood) research on the role of earthworms in soil production was a significant step in understanding the delicate balance of soil dynamics. ${ }^{47}$

In Malaya, Logan supported the theory that the 'mountain forests' played a large role 'in attracting and condensing clouds, diminishing local temperature, and increasing humidity'. Without them, the 'mountain soil, a natural reservoir, would be baked dry in the harsh sun', contributing 'to the severity and longevity of droughts'. ${ }^{48}$ Although drought is not something commonly associated with the tropics, the possibility of drought in Malaya was real. In the mid-1860s, for example, A. C. Maingay, Assistant Residency Surgeon for Malacca, argued that value of the forests lay not only in relation to their economic function but also in their 'climatic influence'. He drew attention to what he termed flaws in the current system of land use. Squatters had the right to fell or burn timber for tapioca cultivation, but the tapioca, he claimed, exhausted the soil in two to three years. This forced the squatters to leave and establish a new site by clearing more forest. The old site would regrow, but with 'brush and thin timber' instead of the dipterocarp trees of the original virgin jungle. The resultant 'ruin of the forest' caused a 'diminution of the rain fall

44 James Low, A Dissertation on the Soil and Agriculture of the British Settlement of Penang ... (Singapore: Singapore Free Press, 1836), 3.

45 James R. Logan, 'The Probable Effects on the Climate of Pinang of the Continued Destruction of its Hill Jungles', Journal of the Indian Archipelago and Eastern Asia 2 (1848): 534.

46 James Hutton, 'Theory of the Earth: or an Investigation of the Laws Observable in the Composition, Dissolution, and Restoration of Land upon the Globe', Transactions of the Royal Society of Edinburgh 1, no. 2 (1788): 209-304.

47 Montgomery, Dirt, 9-14; Charles Darwin, The Formation of Vegetable Mould, Through the Action of Worms, with Observations on their Habits (London: John Murray, 1881), doi.org/10.5962/bhl.title.107559, especially Chaps 3-5.

48 Logan, 'The Probable Effects on the Climate of Pinang', 534-5. The paper was likely one of the influences on J. S. Wilson, whose work on desiccation is cited by Richard Grove as 'seminal': Grove, Ecology, Climate and Empire, 17-22. Logan's study of Penang is quoted almost verbatim in J. S. Wilson, 'On the progressing desiccation of the basin of the Orange River in Southern Africa', Proceedings of the Royal Geographical Society 9 (1865): 106-9. 
[sic] and a general average elevation of the temperature', ultimately 'increasing [the] prevalence of long droughts'. ${ }^{49}$ Such reports had resonance in the evolving global discourse of denudation, desiccation and erosion, especially studies of drought and desertification in northern China and Africa.

\section{Toward preventative measures? Attitudes toward erosion, c. 1920-40}

Despite the availability of expert knowledge in Malaya, it was the 1930s before erosion began to be tackled for its own sake. Thus it was that William OrmsbyGore, Under-Secretary of State for the Colonies, compared Malaya unfavourably with Ceylon in 1928, stating that you can go through miles and miles of country ... [in Malaya] and see the soil being washed away, pure earth wasted and steady deterioration going on'. ${ }^{50}$ Headlines throughout the '30s proclaimed Malaya to have 'Less Soil Each Year' and warned of 'Soil Erosion Danger', yet strongly advised that 'Food Production in Colonies Needs to be Increased'. ${ }^{51}$ The Malayan Department of Agriculture's solution was three-pronged: to penalise those farmers who continued to practise corrosive agricultural methods; to raise awareness of preferred agricultural methods through educating farmers; and to initiate more joined-up working between departments. They issued an advisory pamphlet in English - translated into Malay and Chinese in 1930-which explained to farmers how contour terracing and drainage works would alleviate erosion. ${ }^{52}$ In 1939, the Agricultural Officer of Province Wellesley and Penang-where erosion was a significant problem-embarked on a major educational campaign. A pamphlet was prepared in Chinese, English and Malay to show owners and cultivators of land ... how they can assist themselves and the community as a whole by taking steps to prevent further erosion'.$^{53}$ Coterminous with this effort were an exhibition (reportedly attended by 3,000 hill cultivators), posters and a public lecture delivered in the predominant local Chinese dialect (Hakka) by a newly appointed Chinese Agricultural Officer, Tan Ah King. The department also organised a travelling lecture caravan to reach more remote spots. These labours were critical to reaching

\footnotetext{
49 A. C. Maingay, 'Report on the Timber and Forest Conservancy of Malacca', Straits Settlements Government Gazette 7, Supplement no. 35 (1 September 1865): 387-8.

50 'Soil Erosion in Malaya', The Straits Times, 20 June 1928, 9.

51 'Less Soil Each Year', Malaya Tribune, 3 November 1937, 22; 'Soil Erosion Danger Warning to Villagers', The Singapore Free Press and Mercantile Advertiser, 15 June 1939, 3; 'Warning of Soil Erosion on Penang Hill', Malaya Tribune, 10 July 1939, 12; 'Food Production in Colonies Needs to be Increased', Malaya Tribune, 26 July 1938, 13. 52 Malay and Chinese versions of a pamphlet 'Soil Erosion: What it is and how it might be guarded against'. SEL:SEC:G. 1685/1930. National Archives of Malaysia (NAM).

53 'Warning of Soil Erosion on Penang Hill', Malaya Tribune, 10 July 1939, 12.
} 
secluded, non-English speaking audiences. ${ }^{54}$ By the late '30s, new land leases were approved only on the basis that farmers agreed to implement preventative measures, including terracing and establishing cover crops. ${ }^{55}$

At the same time, the various different departments responsible for lands, forests, mines, agriculture and floods were brought together formally to work on the issue. This reveals a significant change in attitude from the pre-war period. As Conservator of Forests for the Punjab and editor of Scottish Forestry, Robert Maclagan Gorrie (credited as the Scottish 'father of forestry') pointed out in 1938 nothing less than a drastic, extensive multidisciplinary program was needed to fight erosion, one that covered all aspects of plant, soil and animal conservation alongside engineering and agricultural solutions. ${ }^{56}$ That same year, the High Commissioner's office in London had issued a circular asking that erosion be brought under the colonial government's control as a question of policy, as opposed to remaining a specialist concern of a few departments. ${ }^{57}$ This was a critical step toward connecting silos and strategic guidance at the top levels. In Malaya, work undertaken by the various ad hoc soil committees was formalised at the start of 1939 by the creation of a standing central committee to investigate erosion. The committee comprised 10 members: the Advisor on Agriculture; Commissioner of Lands, Straits Settlements; Deputy Commissioner of Lands, Federated Malay States (FMS); Advisor, Drainage and Irrigation; Advisor on Forestry; Director, Rubber Research Institute; Chief Inspector of Mines; a nominee of the FMS Chamber of Mines; and two nominees of the United Planting Association of Malaya. ${ }^{58}$ The committee's composition reveals the enhanced emphasis on creating cross-departmental solutions.

This very much reflected a global change in mindset in the '20s and '30s. The scientists and researchers of this period were able to draw on their personal experiences as international actors, stationed in and travelling across different parts of Asia, Africa and Australia. People like Huxley and Maclagan Gorrie had first-hand experience of erosion and its social impacts. Others, like Hugh Hammond Bennett, had global vision. Hammond Bennett was a pioneer in promoting soil conservation, often in the face of very vocal detraction. A key figure in early twentieth-century

54 'Soil Erosion Danger Warning to Villagers', The Singapore Free Press and Mercantile Advertiser, 15 June 1939, 3.

55 See, for example, the application of sister and brother Noyah binti Haji Ali and Haji Samah bin Haji Ali for 6 acres at Kuala Jempol: Application to the Land Office, Kuala Pilah, 5 January 1940. Negri Sembilan 62/1940, 1. NAM.

56 R. Maclagan Gorrie, 'The Problem of Soil Erosion in the British Empire with Special Reference to India', Journal of the Royal Society of Arts 86, no. 4471 (1938): 911.

57 Secretary of State's Circular Dispatch 'Measures for the Control and Check of the Spread of Soil Erosion in the Colonies by W. Ormsby-Gore', 27 January 1938. Kelantan 332/1938, 1 \& 1a, 1, 3. NAM.

58 O. E. Venables, Under Secretary to Government, FMS, to the Secretary to the High Commissioner for the Malay States, Singapore, 6 January 1939. Kelantan 817/1938, 3a. NAM; M. C. Sheppard, Atg. Under Secretary to Government, FMS, to the Secretary to the High Commissioner for the Malay States, Singapore, 14 February 1939. Kelantan 817/1938, 5a. NAM; Draft dispatch to Secretary of State in reply to the S. S. \& M. S. dispatch from the Secretary of State, 22 August 1939. Kelantan 332/1938. NAM. 
environmentalism, he drew attention to man's role in endangering the fragile interface of soil, land productivity, climate and flooding, partly in response to the Great Mississippi River Flood of 1927 and the Dust Bowl years of the 1930s. ${ }^{59}$ Hammond Bennett's genius came in being able to summarise and promote the problem of erosion across scientific and popular audiences, and to raise governmental awareness and support. While Hammond Bennett was writing largely about the situation in America, his studies had worldwide resonance. Maclagan Gorrie credited the efforts of American agricultural and forestry experts, especially the Soil Conservation Service, with bringing much-needed research and publicity to the problem. He particularly noted their efforts in effecting change in the idea that soil erosion was a 'local' problem and easily dealt with, to being considered as a global problem that required global solutions. ${ }^{60}$ In Malaya, colonial officers looked overseas for guidance in policy and conservation techniques. It was 'most desirable', argued the Director of Agriculture and Director of Forestry in 1930, that 'Malaya should so far as possible profit from the mistakes that have been made in the past in other places'. In particular, he introduced regulations relating to the lease of Crown land then extant in Ceylon, the result of a major governmental report undertaken for that region. This banned clearing vegetation on hills steeper than $45^{\circ}$ (later changed to $40^{\circ}$ ) and enhanced extant measures designed to prevent clearing on major ridges. ${ }^{61}$

Mirroring innovations or regulations used overseas was as problematic as it was useful. The Malayan Land Office, when asked to respond to the $45^{\circ}$ recommendation noted above, responded that ' $45^{\circ}$ is a slope very rarely to be found in Malaya'. ${ }^{62}$ A. T. Newboult, DO at Kuala Selangor, further argued that the topographical maps (for his region at least) were not accurate; thus, he was unable to identify whether a slope was $45^{\circ}$ or more. ${ }^{63}$ Nevertheless, Newboult still looked abroad for the answer, remarking that 'the promised report from Ceylon will doubtless show how this is dealt with there'. ${ }^{64}$

With hindsight, Harold Tempany, Agricultural Advisor to the Secretary of State for the Colonies (previously Director of Agriculture for the Straits Settlements and Malay States), was to acknowledge how over-reliance on imported techniques and

59 For an overview of Hammond Bennett's life and works, see Kevin C. Armitage, 'The Soil Doctor: Hugh Hammond Bennett, Soil Conservation, and the Search for a Democratic Science', in New Natures: Joining Environmental History with Science and Technology Studies, ed. Dolly Jørgensen, Finn Arne Jørgensen and Sara B. Pritchard (Pittsburgh, PA: University of Pittsburgh Press, 2013), 87-102.

60 Maclagan Gorrie, 'The Problem of Soil Erosion', 902.

61 Prevention of the Erosion of Soil in Lands Alienated for Cultivation in the Highland Regions of Malaya, 3 November 1930, 1. SEL:SEC:G 2271/1930. NAM.

62 Land Office to the Resident Selangor, 10 November 1930. SEL:SEC:G. 2271/1930, 3. NAM.

63 District Officer, Kuala Selangor, to the Resident, Selangor, 14 November 1930, 1. NAM, SEL:SEC:G. 2271/1930, 4. NAM.

64 District Officer, Kuala Selangor, to the Resident, Selangor, 14 November 1930, 1. 
methods had made a bad situation worse. ${ }^{65}$ The focus on transplanting 'northern' techniques of land and soil management, he noted in 1950, with 'little appreciation of the peculiarities and dangers inherent in the tropical environment' had in fact exacerbated erosion. ${ }^{66}$

\section{An ongoing disaster, or a problem resolved?}

In 1939, Governor Sir Shenton Thomas responded to Secretary of State for the Colonies Malcolm MacDonald's request for a progress report on the soil erosion situation in Malaya. Calling on various advisors, Thomas concluded his report with his view that 'the ... evidence so far collected serve[s] to confirm the opinion expressed by the late Advisor on Agriculture (Mr O. T. Falkner) ... that "on the whole, the soil of Malaya is nowadays not being washed away on as large a scale nor with as great rapidity as from many countries"'. ${ }^{67}$ The 1939 Malayan report divided progress into two distinct periods, before and after 1920. Since 1920, it was stated, increased attention to the issue had paid dividends, in particular the adoption of new regulations on hill clearing, in combination with educating smallholders about proper drainage and terracing. ${ }^{68}$ Three years later, Tempany offered the same opinion about the global situation. In spite of the war, he argued in 1941, progress on erosion in a majority of dependencies was considered 'satisfactory'. ${ }^{69}$

Despite claims to success in Malaya, problem areas persisted. ${ }^{70}$ The most challenging were steep slopes where pineapple, banana and tapioca crops were grown, especially in Negri Sembilan, the Cameron Highlands and Penang Hill. ${ }^{71}$ The Jelebu district of Negri Sembilan, for example, was famous for its rubber and banana plantations, extensive tin mining and erosion. ${ }^{72}$ Situated in the southernmost section of the Titiwangsa mountain range, the area was also well known for landslips. In 1915, a slip had occurred at Bukit Tangga near an old mining site after heavy monsoonal rains caused large sections of the road toward Titi in the adjacent valley to collapse.

65 Tempany was later to write The Practice of Soil Conservation in the British Colonial Empire (Harpenden, Herts: Commonwealth Bureau of Soil Science, 1949) based on his own experiences of government programs across different regions, especially Mauritius, the Leeward Islands and Malaya.

66 Harold Tempany, 'Soil Erosion and Conservation in the Colonial Dependencies', Journal of the Royal Society of Arts 98, no. 4821 (1950): 553.

67 Draft Dispatch to Secretary of State in reply to the S. S. Dispatch \& M. S. Dispatch from the Secretary of State, dated 22 August 1939. Kelantan: 332/1938, 7a \&7c, 2. NAM.

68 ibid.

69 Report on Soil Erosion in the Colonial Empire in 1941. CO 852/394/6, f. 37. TNA.

70 Draft Dispatch to Secretary of State in reply to the S. S. Dispatch \& M. S. Dispatch from the Secretary of State, dated 22 August 1939, 2.

71 ibid.

72 'Rubber Forestry', The Straits Times, 29 August 1933, 6. 
This was only a month after a nearby Port Dickson line railway bridge had been washed out. ${ }^{73}$ Just over 20 years later, a forest officer stationed at Kuala Pilah, Jelebu, told how:

erosion has taken place in the most obvious possible manner, producing a scene to be expected rather in the Tennessee valley than in Malaya and offering a grim warning of what may happen if the land is abused too far. The area in question forms part of a small rubber estate on a northern spur of Bukit Senaling ... when the land was alienated in 1915 it was covered with thick jungle. After alienation the jungle was felled and burned and the land planted with rubber ... the plantation was evidently clean-weeded after the prevailing fashion ... from that time erosion proceeded apace ... on the steep slope, erosion has reached its extreme. Top soil and humus are entirely lost and the rubber trees have died and disappeared except for a few sickly stumps standing gaunt and precarious with their roots undermined and exposed. ... Gully formation is well under way ... a deep chasm has been torn in the soil exposing the hard un-weathered subsoil below while elsewhere incipient gullies are to be found ... the proprietor has lost his land as an economic asset ... [and] the wash down of sand has ruined the padi for the farmers below. ${ }^{74}$

At Penang Hill, erosion, flooding and landslips were similarly grave. The hill overshadowed historic Georgetown and Ayer Hitam, the latter village the source of Georgetown's freshwater supplies. A Hill Lands Ordinance enacted in 1937 had enabled the appointment of a Hill Lands Officer in 1938 and, importantly, a Chinese Agricultural Assistant (Hill Lands) in $1939 .{ }^{75}$ Drastic action was necessary, as despite the thousands of dollars ... being spent annually to clear rivers and streams of silt, soil erosion continues' ${ }^{76}$ The ordinance targeted Chinese vegetable farmers, whose hillside cultivation practices were blamed for generating soil wash onto padi farms and for polluting the urban water supply. ${ }^{77}$ Under the provisions of the ordinance and the new team, a significant effort was made toward educating local smallholders and farmers as to the 'proper' methods of cultivation that would avoid exacerbating erosion. The ordinance also enabled firmer legislative and regulatory measures to be put in place. Under its terms, around 200 Chinese farmers were required to discontinue planting on the hill slopes of Bukit Gambier and Paya Terubong, close to Ayer Hitam. This scheme resettled those farmers on land allotted them by the government. The farmers objected, arguing that they would be impoverished if they moved. The original scheme had not provided a clause for compensation and,

73 'Public Works in The F.M.S.', Malaya Tribune, 20 July 1916, 11.

74 'Padi Land Ruined By A Planter', The Straits Times, 21 August 1936, 19.

75 Draft Dispatch to Secretary of State in reply to the S. S. Dispatch \& M. S. Dispatch from the Secretary of State, dated 22 August 1939, 5.

76 'Fighting Menace Of Soil Erosion In Penang', The Straits Times, 12 July 1939, 18.

77 Kathirithamby-Wells, Nature and Nation, 175. 
facing demands from the farmers, the government reluctantly agreed that \$40-80 reparation (proportionate to household size) be awarded along with the month's notice to leave. ${ }^{78}$

Riverine flooding - thought to be exacerbated by bankside clearance and cultivation and soil erosion-was also considered to be increasing in frequency and severity after $1920 .{ }^{79}$ In Pahang and Kelantan, two states that suffered especially from heavy monsoonal rains, and at Kuala Kubu and Fraser's Hill in northeast Selangor, excessive mining, land clearances and changes to natural watercourses were wreaking havoc. In Kelantan, for instance, a 1938 Agricultural Department report noted how landslips were contributing to river siltation and, whilst arguing that the practice of clean weeding had never become the 'fetish that it [had] in many of the West Coast Estates', the slips were in large part due to gully erosion caused by Chinese rubber planters' clean-weeding practices. ${ }^{80}$ The combined reports of the Lands and Mines, and Drainage and Irrigation Departments a year later similarly highlighted the severity of matters in that state. ${ }^{81}$

In Province Wellesley, the government granted an extra $\$ 30,000$ on top of normal grants to deal with 'some serious flooding' in 1925. The stated cause was 'the clearing of land and cultivation within the catchment area, together with the construction of dams by various cultivators for the purpose of protecting their lands from flooding, ${ }^{82}$ Erosion there had caused 'thousands of tons of precious topsoil ... [to be] ... washed into ravines and rivers' to an extent that 'cannot be calculated', claimed one horrified commentator. ${ }^{83}$ While there was legislation in place to reserve river banks- 50 yards on either side of the river in Pahang and 12 yards in the Cameron Highlands, for example-it was not always observed. ${ }^{84}$ By 1927 , the problem was so critical that a special investigative committee was convened. One year later, the committee presented their first formal report. "While a variety of factors have contributed towards the deterioration of the rivers in Malaya', the report observed:

78 'Farmers' Dispute with Govt. Ends', Malaya Tribune, 23 August 1940, 3.

79 Draft Dispatch to Secretary of State in reply to the S. S. Dispatch \& M. S. Dispatch from the Secretary of State, dated 22 August 1939, 5-6. For an historical precedent, see Forest Reserve Commission to Government, 16 January 1878. British Library, India Office Collections; Proceedings of the Madras Board of Revenue, 27 August 1878, no. 2400. British Library, India Office Collections: '[A]ny extensive denudation near the sources or along the course of streams must of necessity be followed by destructive floods'. Quoted from Sutton, 'Redeeming Wood', 103.

80 Letter to the British Advisor at Kelantan with accompanying report on Soil Erosion, 29 March 1938. Kelantan 332/1938, 3 \& 3a, 1-2. NAM; Letter to the British Advisor for the Department of Agriculture, Kota Bharu, 29 March 1938. Kelantan: 332/1938, 3. NAM.

81 Memorandum by the Legal Advisor Kelantan, 4 May 1939. Kelantan 413/1939, 3. NAM.

82 Motion by the Colonial Engineer for a special vote of $\$ 30,000(£ 3,500)$ to meet expenses in connection with a scheme to deal with some serious flooding in the vicinity of Sempang Ampat, Southern District, Province Wellesley. RM I.E/59, 1925, Appendix B161. National Archives of Singapore (NAS).

83 'Precious Topsoil', The Straits Times, 25 September 1935, 17.

84 Draft Dispatch to Secretary of State in reply to the S. S. Dispatch \& M. S. Dispatch from the Secretary of State, dated 22 August 1939. Kelantan: 332/1938, 7a \& 7c, 5-6. NAM. 
there is no one factor which has played a more important part than the presence of large quantities of sand, resulting from mining operations, in the beds of a number of the rivers and their tributaries ... Landslides on our mountain sides are not infrequent, and erosion at the head waters of every river is continuous ... Every fall of rain washes surface soil from thousands of acres of tilled and cultivated lands towards our river courses ... [and] Vast areas of land have been, and are being, denuded of their forests. ${ }^{85}$

Flooding was so severe that the American consul in Malaya felt it warranted a special report to Washington in 1928. Noticing that although floods were not a new issue:

[their] seriousness is increasing with the industrial development ... Yearly, the many streams in Malaya have ... overflowed their banks causing serious damage to property and life ... At times entire villages have been completely wiped out, rubber estates have been destroyed and other damages following flood seasons have been apparent. ${ }^{86}$

It was quite apparent to the officers working in Malaya that 'soil erosion and flood control are closely connected'; thus, preventative solutions had by necessity to be threefold: the afforestation of steep slopes and the safeguarding of agricultural lands, in combination with engineering works to provide flood control. ${ }^{87}$

\section{Soil narratives: The muddy waters of blame}

Some contemporary commentators believed that erosion had ushered in an era of 'starvation', as opposed to the 'prosperity' that the empire ought to have delivered for many. ${ }^{88}$ While acknowledging that government, plantation owners, developers and small-scale subsistence farmers all had some share of the blame, there was a tendency to blame the 'junglier $[s i c]$ and more ignorant occupants of undeveloped and backward tracts' for worsening the problem by denuding slopes and catchment areas. ${ }^{89}$ Such rhetoric was nothing new. Discussions during the first and second British Empire Forestry Conferences held in 1920 and 1923 raised how shifting cultivation (normally taken to be traditional/native practices) had destroyed thousands of acres of forest land across the empire. ${ }^{90}$ Such language finds resonance in

85 'The Malayan Rivers', The Straits Times, 5 May 1928, 2.

86 Report sent from the American Consulate at Singapore to the Secretary of State, Washington, 30 August 1928. M712/15, ff. 173-4. NAS.

87 Soil Erosion, by Lt. Col. P. McNee, Irrigation Department Kuala Lumpur, 19 November 1945. MU 1963/46, 8a. NAM.

88 Maclagan Gorrie, 'The Problem of Soil Erosion', 919.

89 ibid., 912.

90 E. P. Stebbing, 'The Forests of India', Journal of the Empire Forestry Association (1922): 269-70; Powell, 'Dominion over palm and pine', 864. 
the words employed by Tempany's successor in Malaya, O. T. Faulkner. ${ }^{11}$ Faulkner's claim that the farmer of alienated land 'can if he likes, whether through ignorance or because his occupation is temporary, ruin his land unless the District Officer takes action' strongly suggests that he fully expected such behaviour from smallholders. ${ }^{92}$ His statement reveals the framing of smallholder and DO in binary opposition in his mind, representing uneducated and educated respectively. The idiom was not uncommon. Echoed by Sir Daniel Hall, Director of the British John Innes Horticultural Institution, he judged it the difficult task of the imperial authorities to dissuade people accustomed to performing age-old agricultural procedures from their folly. ${ }^{93}$ Hall's sentiment was iterated more vehemently by Sir Reginald Glancy (then a retired member of the Council of India and an advisor to the Secretary of State for India) in $1938 .{ }^{94}$ Glancy was certain that, a generation earlier, firm legal orders and the employment of forced labour would have managed the task at hand. Today, he opined, the government's softly-softly approach to the masses had rendered that impossible. ${ }^{95}$

The situation was appreciably more complicated than the dichotomy suggests. It was clear to many actively involved in the field that 'civilisation'-i.e. the structures of life imposed by colonising Europeans-was a principal factor in generating the conditions that had amplified and perpetuated land degradation. ${ }^{96}$ Indeed, G. T. Stanley Clarke, retired District Commissioner to Basutoland, claimed in 1942 that the only way to understand the contemporary situation was through history. While acknowledging the role of changing climatic conditions in causing erosion, for the most part he blamed the actions of avaricious Europeans. The European had exhausted the soil 'to a greater extent than nature intended', he said, going far beyond the smaller-scale farming practices of indigenous cultures. ${ }^{97}$ Tempany also convincingly advocated this view. He viewed colonisation as the element that had tipped the delicate balance from a natural/small-scale process of attrition to a manmade disaster. 'The indigenous inhabitants of erosion-prone lands are invariably aware of the dangers' - he argued in a lecture given in 1950- 'were this not so they could not have survived, as they have done, for thousands of years'. But the 'penetration of erosion-prone lands by northern races [which] has been going on with unparalleled

91 Faulkner served in this post from 1936 until 1938, when he left to take up the position of Principal of the Imperial College of Tropical Agriculture, Trinidad. 'Former Malayan Official At Trinidad', The Straits Times, 13 April 1940, 14. He was previously Director of Agriculture in Nigeria, 1921-36: 'Dr Tempany's successor', The Straits Times, 17 April 1936, 12.

92 O. T. Faulkner, Director of Agriculture (S[traits] S[ettlements]), to the Colonial Secretary, 31 March 1938. Kelantan 817/1938 1 Appendix, 2. NAM.

93 Meeting discussion minuted in Maclagan Gorrie, 'The Problem of Soil Erosion', 925.

94 'Sir Reginald Glancy', The Straits Times, 10 December 1939, 1.

95 A useful exploration of such attitudes is provided by Ramachandra Guha, 'Forestry and Social Protest in British Kumaon, 1893-1921', Subaltern Studies 4 (1985): 54-101.

96 Huxley, 'The Menace of Soil Erosion': 361; Tempany, 'Soil Erosion and Conservation', 552; Maclagan Gorrie,

'The Problem of Soil Erosion', 902, 912.

97 Soil Erosion (Part 1), 20-1. CO 852/394/14. TNA. 
rapidity' introduced methods that surpassed 'the traditional shifting cultivation of primitive peoples [that had in] unmodified form provide[d] safeguards' ${ }^{98}$ As Huxley had also argued, the 'white man' had modified 'the cycles of nature'. ${ }^{99}$ Nevertheless, nobody proposed a return to a pre-colonial state as a solution. In fact, erosion was increasingly used as an argument against self-governance. Maclagan Gorrie's perspective was that only a well-intentioned autocracy had the means to push through the complex and comprehensive legislation necessary to combat erosion. A democratic government elected by the uneducated masses would not have the requisite skills or authority to manage such a pervasive and deep-rooted problem. Such a government would be possible only after many years of investment by the British in widespread educational initiatives. ${ }^{100}$ Huxley also argued in 1937 that colonial governments had a duty to be more hands-on, even so far as intervening in 'tribal habits and customs' if they were considered damaging. Official reticence to interfere in customary land management practices, she claimed, stemmed from 'an acute fear of criticism' made real in the regular dismissal of colonial officers who were considered too heavy-handed. The culture of caution was at odds with the level of intervention required. An effective solution could be achieved only by a resolute government who were prepared to use force, if necessary. ${ }^{101}$

In January 1942, everything was to change. British Malaya capitulated to Japanese invading forces and was occupied until September 1945. When British rule resumed in 1945 under the emergency British Military Administration (BMA) Government, a series of investigations was commissioned to evaluate the extent of damage to forests, plantations and agricultural land across the peninsula. The commanding Chief Royal Engineer warned of the 'possibility of a major catastrophe resulting from the irresponsible clearing of land unsuited for intensive cultivation'. ${ }^{102}$ The Japanese, it was claimed, 'had destructively exploited all accessible forests in the country without regard to the great danger of soil erosion'; ${ }^{103}$ had encouraged dangerous ladang (shifting cultivation); ${ }^{104}$ discontinued the pre-war policy of preventing extensive jungle clearances on steep hillsides; and felled thousands of acres of rubber trees peninsula-wide. ${ }^{105}$ These practices had had the knock-on effect of causing 'extensive damage to anti-malarial and other engineering works ... the silting up of ... water suppl[ies], irrigational channels and padi fields' ${ }^{\prime 106}$ and it was feared that

\footnotetext{
98 Tempany, 'Soil Erosion and Conservation', 552.

99 Huxley, 'The Menace of Soil Erosion', 367.

100 Maclagan Gorrie, 'The Problem of Soil Erosion', 911.

101 Huxley, 'The Menace of Soil Erosion', 368-9.

102 Soil Erosion: Forest and Estate Areas felled by Japanese, 30 October 1945. SEL:SEC 282/1945, 3. NAM.

103 'Repairing Jap Damage To Malayan Forests', The Straits Times, 19 August 1946, 3.

104 Tempany, 'Soil Erosion and Conservation', 555-6.

105 Provisional Statement of Estate Rubber felled during Enemy Occupation, 17 January 1948. SEL:SEC 282/1945, 118a. NAM.

106 W. A. Goode, Chief Secretary, to the Secretariat, Malayan Union, 26 June 1946. R. C. 336/1946. NAM.
} 
more 'silting and flooding, and consequent damage to crops' would be the result. ${ }^{107}$ The BMA's difficulties were surmounted by the loss of many records during the war. This included legislation to check erosion and curtail shifting cultivation practices drafted in the very active period of $1937-40 .{ }^{108}$

Whilst the official correspondence lambasted Japanese land management practices, there is some sense that the damaging effects of occupation were exaggerated. An interesting column written by the journalist Dickson Brown in 1945 suggests another side to the story. Fully prepared to see the ravages of war and occupation on Malayan rubber estates in the anti-Japanese hype of 1945, Brown undertook a tour of the southern peninsula. He was surprised to note that 'not once during that journey did I see a single rubber tree that had been tapped during the past three years'. Interviewing the returning plantation owners, he found that not only had the Japanese not tapped the rubber-preferring to rely on imports from Indo-Chinathe majority of estates were in better condition than before the war. This was because neglect had resulted in a 'luxuriant growth of cover plants or weeds' that protected the plantations from erosion. ${ }^{109}$ Brown's investigative journalism had focused only on rubber, but the findings of his 700-mile round trip and interviews with people in the field ought not to be dismissed. Indeed, they contribute to evidence of a narrative of blame that the British were all too eager to develop to deflect from their own policy failures.

After the Second World War, erosion worsened in many parts of Malaya. Stretched resources, a result of the post-war rehabilitation, prolonged disruption to normal economic activities, and a severe food shortage put pressure on the land. Many areas previously given over to recreation, or that had lain fallow, were forced into agricultural use both during and immediately after the war. The 'Grow More Food' campaign and the 'Short Term Food Production' campaign initiated by the BMA in 1946 opened the floodgates for farmers to cultivate more areas than ever before under Temporary Occupation Licences (TOLs), the latter described as little more than 'vandalism' by the historian Tim Harper. ${ }^{110}$ When the government rescinded these rights in 1948, they were left with an ecological, and social, disaster. The combination of temporary licences and a post-war increase in illegal farming brought erosion back up to levels not seen since the aftermath of the Great War. ${ }^{111}$ In Batu Arang, Selangor, for instance, the Assistant Civil Affairs Officer noted how squatters

107 Soil Erosion: Forest and Estate Areas felled by Japanese, 30 October 1945. SEL:SEC 282/1945, 3. NAM.

108 Tempany, 'Soil Erosion and Conservation', 555.

109 Dickson Brown, '700 Mile Tour Of Malayan Rubber Areas', The Straits Times, 23 September 1945, 4.

110 Tim Harper, The End of Empire and the Making of Malaya (Cambridge: Cambridge University Press, 1999),

102. Copy of minutes from a meeting on the subject of soil conservation in short term food production, held 23 September 1946. SEL: SEC. 282/1945, 68-86a. NAM.

111 Soil Erosion: Forest and Estate Areas felled by Japanese, 30 October 1945. SEL: SEC 282/1945, 4b. NAM. 
had cleared 1,000 acres of jungle to plant food crops. ${ }^{112}$ The intense pressure to produce enough food to meet needs demanded that reserved land be made over to food production. ${ }^{113}$ Thus legal, as well as illegal, clearances increased significantly over the late' 40 s.

Near Kuala Lumpur, this compounded river siltation and contributed to flooding in an area already well known as a trouble spot. ${ }^{114}$ The situation was especially bad at Beranang, Rinching, Semenyih and Ulu Langkat, where considerable quantities of soil were washed down from the Negri Sembilan hills. ${ }^{115}$ The deluge of concerned reports from DOs from across the same area, testifying to illegal clearing, damage and fears that floods would only intensify as a result, articulate a deep sense of unease. At Sungai Buloh, for instance, the problem was especially acute. District Commissioner A. B. Ramsey and the Director of Drainage and Irrigation, W. Grantham, noted in 1946 how the Short Term Food Production area at Ulu Buloh and Endau was causing serious sheet erosion and siltation in Sungai Buloh and Sungai Damansara, with heavy washing into Sungai Kembit. ${ }^{116}$

Government strategies toward the Chinese vacillated between tough and conciliatory. Penang Hill is a case in point. An area highlighted as severely eroded before the war, the situation had only worsened. Frightening reports in 1947 claimed that within just six months Chinese cultivators on Penang Hill had caused six inches of topsoil to wash into padi downhill. ${ }^{117}$ The Collector of Land Revenue, V. E. Dawson, issued the dire warning that the area was in danger of becoming a 'bare, forbidding rock'. ${ }^{118}$ British policy at Penang from the late '30s until the end of 1941 had been to resettle Chinese farmers then cultivating the hill slopes. In 1947, the BMA discovered that at least 400 of those ordered to leave in 1941 had, in fact, remained. Rather than evicting the farmers outright, Dawson explained that 250 permits had been issued in March 1947, a number that had increased to 460 by June, the majority of which related to holdings on the Paya Terubong and Relau sides of Penang Hill. The permits were issued 'on condition that holders take all necessary anti-erosion measures to protect padi and other food areas in the lowlands and to check any threat to the hill itself'. ${ }^{119}$

112 Report of the Civil Affairs Office, Batu Arang, to S.C.A.O., Selangor, 29 March 1946. SEL: SEC 282/1945, 11. NAM.

113 Series of letters and memos on soil erosion and emergency food production in Selangor, 30 July 1946 - 21 July 1947. SEL: SEC 282/1945, 58-94. NAM.

114 Extract from the Weekly Food Situation Report of the S.A.O, Selangor, 15 July 1947. SEL: SEC 282/1945, 95. NAM.

115 Soil Erosion in the Beranang Catchment Area, 23 August 1946. SEL: SEC 282/1945, 63. NAM.

116 Director, Drainage and Irrigation, to the Chief Secretary, Kuala Lumpur, 24 May 1946; District Commissioner

(Coast) to the Resident Commissioner Selangor, 10 July 1946. SEL: SEC 282/1945, 22, 46. NAM.

117 'Penang Hill is Six Inches Shorter Now: Farmers Cause Erosion', Malaya Tribune, 8 March 1947, 5.

118 'Erosion Threat to Penang Hill', The Straits Times, 10 June 1947, 4.

119 ibid. 
An oft-repeated attitude of post-war government officials was that the erosion problem would be solved only if the affected areas were 'rid' of the Chinese cultivators. ${ }^{120}$ This was not considered an 'easy matter as the Chinese concerned are both numerous and inclined to be stubborn'. ${ }^{121}$ In the immediate aftermath of the war, nothing short of military assistance was deemed necessary to force the Chinese cultivators, due to their resistance and, in some cases, even violence. ${ }^{122}$ Removing the legally authorised farmers after their TOL had expired was also challenging:

it should be realised that the Chinese, admirable as they are in certain forms of agriculture, have a very bad record when it comes to Temporary Occupation Licences on undulating or steep land. The exploited lands of Malacca, Southern Negri Sembilan, Johore and Singapore Island, the result of uncontrolled gambier and tapioca planting in the past[,] are known to all of us. The more recent rape of parts of Jelebu District by Chinese planting bananas is less well known. They are now out to repeat this in the Genting Sempadan area if their efforts are not controlled in time. ${ }^{123}$

While there is no doubt that the occupation had left a momentous task of ecological reconstruction, the perpetuation of a blame culture toward the Japanese within the soil erosion narrative was a convenient way to deflect from any perceived failings of British Government environmental policy after 1946. With the intensification of a 'striking interim assertion of imperialism' amidst renewed calls for independence and increasing conflict with the Malay elite, more traditionally supportive of British rule, a Japanese scapegoat was a canny political weapon. ${ }^{124}$ The balance of blame tipped between Japanese and Chinese from late 1945 to 1946, steadily increasing over the late '40s. Although Chinese farmers had been held responsible before the war, this time the narrative had undergone a disturbing shift. Unlike the more measured way they had been dealt with previously, with educational programs and compensated resettlement, now they were more often likely to be forcibly resettled or prosecuted. This shift represented the different scales of the problem before and after the war, but also the British Government's changing attitude toward the Chinese. The declaration of a State of Emergency in 1948 had the ironic and probably unintended consequence of enabling the government to remove squatters practising shifting cultivation in a way and to an extent that could not have been imagined

120 Letter on Soil Erosion from the Forest Office, Kuala Lumpur to the Chief Secretary, HQ, BMA, 1 November 1945. SEL: SEC 282/1945, 4b. NAM.

121 State Agricultural Officer, Pahang, to the Resident Commissioner of Pahang, 24 March 1947. MU 1963/46, 45b. NAM.

122 Memo to the Chief Secretary, HQ, BMA Kuala Lumpur from Lt. Col. J. P. Mead, Officer-in-Charge, Forests, 16 November 1945; S.C.A.C. Works to the Chief Secretary, HQ, BMA, Kuala Lumpur on Prevention and Cure of Damage by indiscriminate felling in Jungle areas, 11 January 1946; Copy of a minute by Col. M. C. Hay in R.C. Johore, 12 April 1946. MU 1963/45, 5b, 8, 20a. NAM.

123 State Agricultural Officer, Pahang, to the Resident Commissioner of Pahang, 24 March 1947. MU 1963/46, 45b. NAM.

124 Martin Thomas, Bob Moore and L. J. Butler, Crises of Empire: Decolonisation and Europe's Imperial States (London: Bloomsbury Academic, 2015), 42. 
before the war. This involved the forcible removal of rural farmers and squatters (the majority of them Chinese) to 'new villages' - essentially guarded camps-legally under the terms of the Emergency.

\section{Conclusions}

In 1950, Tempany had claimed that great progress had been made in curtailing erosion globally, especially in Malaya where 'erosion on estates, at one time serious, has been largely checked'. Tempany's statement might have been a little premature. In 1952, an official statement from the Department of Agriculture pointed out that 'the danger of erosion is very real'. ${ }^{25}$ The situation at Pahang and Negri Sembilan was still worrying local officials, especially in Negri Sembilan where 'defiant' cultivators were preventing real progress. ${ }^{126}$ Erosion also persisted in Selangor, especially around Sungai Buloh, Sungai Damansara and the Klang River catchment, as before. ${ }^{127}$ Whilst Tempany may have painted an overly rosy picture of Malaya's situation, he realised that much more was necessary to combat the problem across the colonial empires. More research was needed on basic soil science, climate and vegetation, he argued, alongside education for the native populations. Last, but not least, he criticised the over-reliance on data from the United States, as opposed to learning from experiential practices in Africa and Asia, especially the disinclination to link land strategies with the 'social ... side' of native and local cultures. ${ }^{128}$ In these statements, Tempany had hit the nail on the head in understanding that preventing erosion was a far more complicated matter than a simple top-down imposed land management policy could tackle.

The understanding of the causes of soil erosion tied in with wider progress in the science and understanding of the soil, and the connections between agricultural practices and erosion. In most cases, interpretations of erosion in Malaya were objective, rational and scientific. But it is hard to avoid noticing how allocating blame for the problem changed, largely corresponding with the political scapegoats of the time. Before the war, it had been the shifting cultivators, Malay or Chinese, whose supposed ignorance of 'proper' land management techniques had contributed to erosion, alongside a wider narrative of European colonial failure. During and immediately after the war, the Japanese were culpable. After 1945-46, the Chinese

125 Letter on behalf of the Member for Agriculture and Forestry, Federation of Malaya, to the State Secretary, Selangor, 4 March 1952. 357/1949, 22. NAM.

126 Soil Erosion: Present Position in the respective states, summarized from reports from State Agricultural Officers, 1947. MU 1963/46, 46. NAM.

127 District Officer, Ulu Selangor, to the State Secretary Selangor, 2 September 1949; District Office, Kuala Lumpur, to the State Secretary Selangor, 12 September 1949. SEL: SEC 359/1949, 12, 13. NAM.

128 Tempany, 'Soil Erosion and Conservation', 555, 561. 
were increasingly targeted, a situation that intensified as we move toward the Emergency of 1948. The deflection of responsibility to different parties could thus be considered part of a wider political narrative.

This article has largely concentrated on the situation from the top down and the attitudes of the British officials engaged in forestry, land management and governance. This perspective represents just the tip of the iceberg. While undertaking research for this article, the records revealed tantalising glimpses of ordinary people's responses to governmental interference in their agricultural activities, many of which were integral to long-held cultural beliefs and practices, or simply their survival. While it may have been an inconvenience to government to resettle smallholders, the 'inconvenience' to the farmers who had to start afresh must have been intense. At the same time, however, the impact of soil erosion would have been felt in declining harvests or, more dramatically, in landslips or soil wash onto crops, would have had a severe effect on livelihoods. These stories, and the stories of resistance and accommodation, whilst outside of the scope of this present article, demand to be told. 
This text is taken from International Review of Environmental History, Volume 4, Issue 2, 2018, edited by James Beattie, published 2018 by ANU Press, The Australian National University, Canberra, Australia.

doi.org/10.22459/IREH.04.02.2018.05 